\title{
Public Opinion and Foreign Policy: Analysing Nigerian Reactions to the Asylum Difered Former President Charles Taylor of Liberia
}

\author{
Ojieh Chukwuemeka Ojione*
}

\begin{abstract}
On July 5, 2005, exactly two years after the asylum offer to Charles Taylor in Nigeria became public knowledge, President Obasanjo was at the Assembly of the 5th Ordinary Session of the Heads of State and Government of the African Union, in Sirte, Libya, calling for protection against the harassment of Nigeria by some sections of the international community 'over the country's refusal to surrender former Liberian President, Mr Charles Taylor, to face trials at the International War Crimes Tribunal'. But from the inception, the Nigerian public had virulently opposed the asylum idea. Still, government received Charles Taylor in Nigeria on August 11, 2003. Why? Why was public opinion unable to reverse the state's policy? Using the methodological tool of content analysis, this article identifies the bases of public opposition to the asylum offer, which involves principally a general disdain for the person of Charles Taylor, given his antecedents. Regardless, the Nigerian government went ahead and provided asylum to Charles Taylor, putting what it considered Nigeria's interest first. The government adopted, therefore, a mode of moral judgment that was antagonistic to that of the people whom it is ideally supposed to stand for. The article concludes that the dynamics which characterise the art of statesmanship, in which the primary
\end{abstract}

* Department of History and International Studies, Delta State University, Abraka, Nigeria. 
responsibility is the survival of the nation-state, overpower the potential of public opinion to exert decisive pressure, since the bulk of the public is believed to be largely inarticulate or uninformed.

\section{Resumé}

Le 5 juillet 2005, exactement deux ans après que le droit d'asile accordé à Charles TAYLOR ait été révélé au public, Président Obasanjo prenait part à l'Assemblée de la 5ème Session Ordinaire des Chefs d'Etat et de Gouvernement de l'Union Africaine, à Syrte, en Libye, pour lancer un appel pour la protection du Nigeria contre les harcèlements en provenance de certaines franges de la communauté internationale, dus «au refus du pays de rendre l'ancien Président Libérien au Tribunal Pénal International». Cependant, dès le début de l'affaire, l'opinion publique nigériane s'était farouchement opposée à l'idée de l'asile. Néanmoins, le gouvernement avait reçu Charles Taylor au Nigeria le 11 août 2003. Pourquoi? Pourquoi est-ce que l'opinion publique n'a pas réussi à changer la décision prise par l'Etat? A l'aide d'outils méthodologiques d'analyse du contenu, cet article essaie d'identifier les raisons qui ont poussé l'opinion publique nigériane à s'opposer à l'asile accordé à Charles Taylor. Il s'agit principalement d'un mépris généralisé pour Charles Taylor en raison de ses antécédents. En revanche, le Gouvernement avait privilégié ce qu'il considérait être l'intérêt du Nigeria, en exigeant une autre forme de jugement moral différent de ceux des individus, et décida d'accorder le droit d'asile à l'ancien Président du Liberia. Lauteur conclut l'article en déclarant que la dynamique qui caractérise l'art de la diplomatie, dont la responsabilité primordiale consiste à assurer la survie de l'Etat-Nation, l'emporte sur la capacité de l'opinion publique à exercer une pression décisive, étant donné que la plus grande partie de la population est supposée être incapable de s'exprimer ou est mal informée.

\section{Introduction}

In 1816, the Virginia-based American Colonization Society asserted that there was a need to resettle some of the 1.5 million blacks, most of whom were freed slaves, somewhere in Africa if there was not to be a social crisis. Present-day Liberia became the choice and some of the freed black slaves began emigrating to it from 1822. These returnee AfricanAmericans who became Americo-Liberians, together with the autochthonous people, achieved independence for Liberia on 26 July 1847. 
Things went wrong from the beginning as the settler Liberians constituted only five percent of the population. Perceiving themselves as a superior group, they arrogated to themselves the 'civilising mission' of the 'inferior' indigenous group, by propagating discriminatory policies under predominantly migrant Liberians' dominated governments. For over a century, between 1847 and 1980 when Samuel Doe became President, only Americo-Liberians had ruled Liberia. The 95 percent of the population who were indigenous resented this situation. Hence, when he staged his coup and, albeit temporarily, halted the political dominance of the settler group, Doe won popular support.

Samuel Kanyon Doe had ridden on the crest of popular support from all segments of the indigenous Liberian population after his April 12, 1980 'revolution' to become President of over two million Liberians at the age of 30. No sooner had he settled down to office than he embarked on the elimination of all forms of opposition, whether real or perceived. Hence, of the seventeen of those who had staged the coup in 1980, including Samuel Doe himself, Thomas Wey Syen, Thomas Quiwonkpa, Abraham Kollie, Nicholas Podier, Fallah Vanney, Jeffery Gbatu, Larry Bortey, Harrison Penue, Robert Sumo, Harrie Johnson, Harry Zuo, Jacob Swen, Albert Toe, Nelson Toe, William Gould, and Kolonsh Gonyon (Omoninjo 2003: 19); by 1990, Doe had eliminated sixteen. A decade after he became President, life in Liberia had become unsafe and all the popular politicians joined forces calling on Doe to quit.

Charles Taylor was a Baptist Church preacher in Liberia before Samuel Doe appointed him to his cabinet. His portfolio placed him in charge of the procurement of government requirements. Relations between the two turned sour. Taylor was indicted for stealing 800,000 Liberian dollars and took flight to the US. Although detained, he escaped from jail before the US authorities could extradite him. He landed in Libya where he received military training. Backed by Libya, Côte d'Ivoire and Burkina Faso, he launched an attack on Doe on December 24, 1989, marking the beginning of the conflagration that engulfed Liberia until recently. In the course of the conflict, former President Samuel Doe was murdered by the Yormi Johnson-led rebel faction of the National Patriotic Front of Liberia on September 9, 1990.

Charles Taylor was inaugurated as Liberian President on August 2, 1997, after Liberia had tinkered with an interim government and other peace initiatives between 1992 and 1997. But the peace which this engendered was only tentative as the crisis resumed as from September, 
1999. Once again, it was reasoned that like Doe, Taylor must be the Liberian problem personified, and for Liberia to have peace he must be removed because, as expressed by Nigeria's President Obasanjo, 'Charles Taylor may stay here and say he will fight to the finish and if Charles Taylor fights to the finish, there will be no peace' (Eze 2003:2). Taylor was removed via an asylum offer by Nigeria.

If there is any Nigerian government foreign policy gesture that has in recent times generated considerable public outcry, it is the issue of Nigerian involvement in Liberia. It is one foreign policy undertaking that has had a profound effect on a generality of the citizenry of Nigeria, if only because it was public knowledge that Nigerian soldiers were fighting a war in in that country. Nigeria in Liberia was topical among thousands of Nigerian families whose members were directly involved either as peace keeping soldiers, journalists, etc., or as returnees from the war-torn country. Its effects on even some of the most remote settlements of Nigeria were tangible, as after Federal officials had received the returnees from Liberia, in relay form, individual state governors and officials received their indigenes and passed them on to the local council authorities. Individual communities, kith and kin as well as families, had feasted at the safe return of one of their own from Liberia. In the conflict Charles Taylor's rebel forces had particularly targeted Nigerians (including those formally residing there), for elimination on account of the perceived support of their government for Taylor's opponents.

\section{Statement of the Problem}

It is probable that Nigerian involvement in Liberia was Nigeria's single largest undertaking (in terms of men and materials) outside its shores. The Liberian crisis has seen Nigeria losing over 1,000 soldiers in the years of intervention between 1991 and 2003, and expenditure had reached \$12 billion (Eze 2003: 2). Two Nigerian journalists; Kress Imodibie and Tayo Owotusin, were killed working in Liberia. The number of civilian causalities will never be known. Needless to say, when on July 6, 2003 it became public knowledge that Nigeria's President Obasanjo had granted President Taylor asylum in Nigeria, the gesture generated a furore. Individual communities such as those of Iviukhua in Edo State, (Kress Imodebie's home town), religious organisations such as the Christian Association of Nigeria (CAN), labour and other interest groups opposed the asylum project. The government went ahead with the project and criticism of its decision continued. 
This article seeks to analyse the reaction of Nigerians to the granting of asylum to Charles Taylor in Calabar, Nigeria. Specifically, it will attempt to answer the following research questions:

(i) Why was the Nigerian public opposed to the asylum offered to former President Charles Taylor of Liberia?

(ii) What were government's justifications for the policy?

(iii) Why was public opinion overridden by foreign policy determinant(s) with regard to the offer of asylum to Taylor?

\section{Theoretical Framework}

In International Relations, the concept of theory has been used interchangeably with ideas of doctrine, philosophy and ideology. This situation makes it easier to ascribe theoretical bases to the foreign policies of the advanced democracies. This is because of the "perceived national and international reality which informs the character of policy choice as well as the ability to predict events and situations and thus act' (Aforka 1988: 40). Theoretical justification for the foreign policies of smaller nations can be attributed to such concepts as Pan Africanism, regionalism, human rights and equality, especially, with regards to the foreign policies of most African states.

For the purposes of this article, decision-making theory is the major framework utilised. As espoused by Asobie in Aforka (1988: 45), decisionmaking theory assumes that foreign policy involves the setting of shortterm goals and the choice of means of attaining such goals. Foreign policy implementation therefore involves a set of ad-hoc and uncoordinated responses to external stimuli. Thus, "the nature of foreign policy determines the characteristics of the foreign policy itself' (Aforka 1988: 46). This has to do with the "in-depth analysis of the bureaucratic framework of foreign policy making' (Stupak 1977: 135).

Hence, the consideration of the various elements of national decision making: the actors, such as top military and diplomatic advisers along with the executive leaders; the internal environment of the state, including the relative expertise and power of various individuals, agencies and organizations ... and the external environment which includes analysis of the power positions of the international actors and the possibility for increasing the state's influence (Stupak 1977: 135). 
Specifically, decision making here places emphasis on the problem of choice among alternative course of actions confronting the decision maker. It is also called statistical decision theory. Here, 'The decision problem under study may be represented by a model in terms of the following elements [or some of them]' (Hamburg 1977: 545):

(i) The decision maker;

(ii) The alternative course of actions;

(iii) Events;

(iv) Payoffs; and

(v) Uncertainty.

A discussion of these elements as they relate to the asylum project is now attempted here.

(i) The decision maker is the agent charged with the responsibility for making the decision and may be an entity, a single individual, corporation, government agency, etc. In the context of Nigeria's offer of asylum to former President Charles Taylor, the decision maker is (or ought to be) a combination of the presidency, the national assembly and the bureaucracy of the external affairs ministry.

(ii) The alternative course of action is the pool of action choices jostling for adoption by the decision maker. It is actually the adoption of any or more of these lines of actions that is the decision itself. The issue is actually how to discern among these options which is the most appropriate in the light of the prevailing circumstances. With regard to Nigeria and the Charles Taylor asylum project, there were these options:

- Handing him over for trials for war and other crimes;

- Asylum in Nigeria or elsewhere;

- Allowing the prolongation of the crisis in Liberia due to his (Taylor's) intransigence;

- Deciding not to act at all, as 'Even choosing not to act is a decision' (Conn 1971: 18).

(iii) Events are occurrences that affect the achievement of the objectives of the decision maker and are outside his control. They are imposed on the decision maker by virtue of the fact that we live in a complex and interdependent society (Conn 1971: 196). 'The events constitute a mutually exclusive and complete set of outcomes; hence, one and only one of them can occur' (Hamburg 1977: 549). No one such single event immediately applies here. But given the atrocities of Charles Taylor, we should consider the reactions of Nigerians, and even 
Ojione: Public Opinion and Foreign Policy

Liberians, to this foreign policy action by the Nigerian government. And what would be the reaction of the international community?

(iv) 'Payoff' refers to the net benefit the decision maker receives for his choice from alternative course of actions in making his decision. More often than not, the core goal of foreign policy is the promotion of the national interest. The extent to which this is safeguarded could be considered the rationale for the Nigeria's grant of asylum to Taylor. This can exhibit itself in an increased esteem for Nigeria among the community of nations if by this action Liberia and hence, the West African sub-region, attains relative peace - especially given the fact that Nigeria received little or no financial assistance for this gesture.

(v) Uncertainty refers to not being sure regarding the reactions or events that a decision will trigger off. It requires the making of predictions or assigning probabilities to events. On the asylum project, this could take the form of Nigeria not being certain of the consequences of its action. It might then position itself for being more or less obliged to hand Taylor over for trial.

The foregoing scenario can be summed up thus: Nigeria, the decision maker, as the natural power broker in the West African sub-region in particular and Africa in general, decided in 1991, among alternative course of actions, to intervene in the Liberian crisis. By the year 2003, when it granted Taylor asylum, it had committed $\$ 12$ billion and lost about 1000 soldiers in peace keeping operations. Even though these efforts were not acknowledged by the world, 'not even in giving us debt relief for the contribution we made' (Eze 2003:1), the gesture was said to be in Nigeria's interest.

\section{Public Opinion: A Conceptual Framework}

One of the criticisms against 'realist' theorists in international relations is the neglect of domestic factors, since they 'typically treat individual nation-states as sovereign systems whose internal politics can be safely ignored' (Peterson 1994: 228). But 'in international relations a dissident minority long has argued for the importance of studying causal links between domestic structures and foreign policy decisions' (Jacobsen 1996: 93). Actually, in the nineteenth century, the extent to which national factors influenced international politics was a dominant research paradigm (Almond 1990: 264).

There are also recent studies which establish that internal factors condition international policies. This has led Kehr (1977: 23) to say 
that, 'A foreign policy has - this may sound trivial but it is often overlooked - not only an antagonistic front of it but a homeland behind it ... it is guided by the will and needs of the homeland, whose concerns are primarily domestic'. No wonder Jacobsen (1996:94) opines that, 'internal factors require attention whenever we set out to explain policy responses to external stimuli'. It is in this light that this study of the role of public opinion in the grant of asylum to Charles Taylor is undertaken.

Public opinion, which is in the realm of domestic political pressures, is one of the many domestic elements that could exert an influence on foreign policy. Another domestic element is economic constraint, which for example minimised Nigeria's capacity to sustain its radical antiapartheid policy. Failing fortunes had made Nigeria embark on a policy of economic diplomacy resulting in its fraternising with the apartheid enclave, contrary to an initial stance of being in 'no haste to lift ... sanctions against South Africa until there was complete dismantling of all structures of apartheid ... and [initiating] the principle of one man one vote' Ojieh (1994: 89). Other domestic factors include domestic interest groups, social ideas, the character of the constitution and social tendencies (Jacobsen 1996: 97).

In its most simplistic form, public opinion means the opinion of the generality of the citizenry. As a determinant of foreign policy, it is the influence of the reactions of the public on the foreign policy actions of governments. One of the earliest references to it as an influence on foreign policy was with regard to Lord Canning who upon succeeding Castlereagh as British Foreign Affairs Minister in 1822 was said to have marked an innovation in the conduct of foreign affairs by appealing for popular approval through brilliant speeches aimed at English public opinion (Richards 1967: 72).

The connotation of the term 'public' here is that 'public opinion' is actually an authentic representation of the opinions of the generality of the people or the public. This kind of generalisation can be hasty and misleading. This is because public opinion has been described as in reality the opinion of an articulate minority, since 'the vast majority of people — even in highly literate societies - are unknowledgeable, uninterested, and apathetic with regards to most issues of world affairs' (Holsti 1977: 392).

This article does not seek to dabble in the debate of how 'public' public opinion really is. What is of importance is that in every society there exists in the words of Deutsch and Merritt 'a small top layer of the attentive public that is reasonably well-informed, articulate and interested' 
(Holsti 1977: 393) in issues of world affairs. More often than not, this 'attentive public' is literate and petit-bourgeois in nature. It is the opinion of this class (which at some instance may galvanise the lower class, essentially to provide a mob) that constitutes public opinion.

\section{Public 0pinion and Nigerian Foreign Policy — A History}

Central to the argument of this paper is that public opinion had and still helps to give direction to the foreign policies of states. Instances abound when states yielded to public pressure despite other preferred options because public opinion had elevated such issues to the top of their foreign policy agendas' (Hocking 1990: 1 18).

Immediately after independence, Nigeria and Britain had concluded a military pact 'to afford each other such assistance as may be necessary for mutual defence and to consult together on measures to be taken jointly or separately to ensure the fullest co-operation between them for this purpose' (Obasanjo 1981: 4). By all standards, this 'was an unequal treaty' which the newly constituted Federal House of Representatives interpreted as 'an attempt [by Britain] to swindle Nigeria out of her sovereignty' (Obasanjo 1981: 3). Public reaction to this pact led by university students and supported by other vehement factions resulted in Nigeria's abrogation of the pact in December 1960.

When in the first week of August 1972 speculation became rife that Rhodesia (now Zimbabwe) was going to participate in the Munich Olympic Games of August to September 1972, even though its racist policy had in no way improved, Nigerians were full of indignation. 'All the Nigerian newspapers ... came out against Nigerian participation in the Games if the Rhodesian team was not excluded' (Aluko 1981: 183). This placed the country in a dilemma given the fact that in September 1971, Nigeria had acceded to Rhodesian participation in the Games when the Supreme Council for Sports in African (headed by Nigeria's Abraham Ordia), reviewed Rhodesian eligibility for the 1972 Games. There was thus a contest between Nigeria's honour by making its word its bond, and reneging on its word by bowing to public opinion. To wriggle out of this predicament, Abraham Ordia and Sir Adetokunbo Ademola, Principal International Olympics Committee officials fronting for the Nigerian government, facilitated Rhodesian expulsion from the Games, citing nontotal conformity with the terms for admission (Aluko 1981: 183).

In 1986, it hit the news-stands that Nigeria was contemplating abandoning its observer status to assume full membership of the 
Organisation of Islamic Countries (OIC). Nigerians of Southern extraction reacted vehemently to this move, which was viewed as tantamount to the renunciation of Nigeria's claim to be a secular state. The reactions were virulent enough to threaten the corporate entity of Nigeria; splitting the ruling class to the extent that it was speculated that the resignation of Vice-President Commodore Ebitu Ukiwe might not have been unconnected with his (Ukiwe's) lack of compromise with others in the hierarchy over the Nigeria/OIC issue (Uzor 1986: 17). At the end of the day, President Babangida, at least, in public, refuted the speculation even though doubts remained.

The same President Babangida had called for a public debate on the viability or otherwise of an IMF loan for Nigeria. An official committee had turned in a 'no-loan' verdict. Once more, President Babangida, claiming respect for public opinion, was to have abandoned the idea. These and other examples suffice to demonstrate that state officials can yield 'to public pressures despite their own preferred policies' (Holsti 1977: 392).

\section{Opinion Polls on Nigerians' Reactions to the Asylum Project}

In the light of the preceding examples, it could be averred that in the event of an unfavourable public opinion, it was possible that the Nigerian government would abandon the asylum project. But first of all, we need to establish what the opinions of Nigerians on this matter were. In gathering the public opinion polls of Nigerians' reactions to the asylum project, the methodological tool of content analysis was adopted. Its choice was principally born out of the enormous cost in money and time of engaging in a nation-wide survey research on a topic such as this, given Nigeria's size, population, and low literacy level. And for government reactions, the choice of content analysis is premised on the fact that since the major actors in foreign policy making that is, the presidency and its advisers, ambassadors and the higher echelon of the Ministry of External Affairs, are not easily accessible to be observed or surveyed by the researcher, the gap is filled by the content analysis tool. Hence, Holsti (1969: 15-16) observes that, "when restrictions of time and space do not permit direct access to the subject of research, they must be studied at a distance'.

The population of documents for this study consists of the daily publications of The Guardian and Vanguard newspapers published from Lagos, Nigeria. The choice of these newspapers is not arbitrary; the extent 
of their national coverage (in the author's opinion) is obvious and the degree of the independence of opinions expressed in them is appreciable at least when compared with their government-owned counterparts. The period of study covers the months of June to August 2003, with regard to issues related to (or references to) the subject of Nigeria's asylum offer to former President Charles Taylor of Liberia. This periodisation was informed by the fact that in the first week of June 2003, peace moves between President Charles Taylor and the rebel groups were underway and when on June 17, a cease-fire was agreed and a peace agreement was signed in Accra, Ghana, its high point was that President Charles Taylor stepped aside. By July 6 , it was already public knowledge that Nigeria was going to be the asylum and there was evidence of Taylor's tacit acceptance of it when he declared that 'We believe that there can be an orderly exile from power' (Okpowo 2003: 12). On August 12, 2003, Charles Taylor arrived in Nigeria for asylum.

The sample of documents for this study consists of one hundred and forty-three articles or references to the subject of Nigeria's asylum to Taylor as published in the aforementioned newspapers during the period of study. These 143 references have been systematically classified into units of analysis or variables to determine the frequency of their occurrence so as to enable us to reach conclusions on their influence on how Nigerians either as individual citizens, groups, professionals, etc., or government, reacted to the asylum project.

Specifically, seven units of analysis are generated, four opposed to the asylum offer and three in support. The various arguments against the asylum offer have been grouped into the four following broad categories:

(i) An objection to the asylum project due to Taylor's antecedents including unfriendliness to Nigeria and Nigerians.

(ii) The involvement in Liberia had constituted a huge drain on Nigeria's economy, and similar gestures by Nigeria in the past were not appreciated by Taylor and his countrymen.

(iii) Taylor was sought for trial by the UN Crimes Court, and there were fears of reprisals from the international community or a possible threat to Nigeria's security.

(iv) The asylum offer flew in the face of public opinion and lacked consultation.

The supporting items are grouped into three main arguments: 
(i) The offer of asylum was in consonance with Nigeria's big brother role in the ECOWAS sub-region and Africa as a whole; Nigeria has done it before; and should do it again.

(ii) The offer was in Nigeria's national interest and boosted its status as a regional and continental power.

(iii) Taylor's exit due to the offer of asylum was synonymous with peace in Liberia and in the entire ECOWAS sub-region.

Table I: A Breakdown of the Frequency Among the Variables or Units of Analysis

\begin{tabular}{|c|c|c|c|}
\hline No. & Variables & 0 & $\%$ \\
\hline (i) & $\begin{array}{l}\text { Objection to the asylum project due to Taylor's } \\
\text { antecedents including unfriendliness to Nigeria } \\
\text { and Nigerians }\end{array}$ & 30 & 21 \\
\hline (ii) & $\begin{array}{l}\text { Asylum project is a huge drain on Nigeria's } \\
\text { economy/similar gestures by Nigeria in the past } \\
\text { were not appreciated }\end{array}$ & 16 & 11 \\
\hline (iii) & $\begin{array}{l}\text { Hand-over Taylor for trails by the UN Crimes } \\
\text { Court fear of reprisals from the international } \\
\text { community/threat to Nigeria's security }\end{array}$ & 34 & 24 \\
\hline (iv) & $\begin{array}{l}\text { It undermines public opinion/lacking in } \\
\text { consultation/gives credence to dissidence } \\
\text { and bad leadership }\end{array}$ & 11 & 8 \\
\hline (v) & $\begin{array}{l}\text { Support for the asylum project; } \\
\text { it is in consonance with Nigeria's 'big brother' } \\
\text { role in the ECOWAS and Africa/Nigeria has } \\
\text { done it before and can/should do it again. }\end{array}$ & 12 & 8 \\
\hline (vi) & $\begin{array}{l}\text { It is in Nigeria's national interest and boost to } \\
\text { its status as a regional/continental power }\end{array}$ & 5 & 3.5 \\
\hline (vii) & $\begin{array}{l}\text { Taylor's exit from Liberia is synonymous to } \\
\text { peace in Liberia and the entire } \\
\text { ECOWAS sub-region }\end{array}$ & 35 & 25 \\
\hline & $N$ & 143 & 100 \\
\hline
\end{tabular}

K ey: $\mathrm{N}=143$ (Total number of referential issues on the subject or (Sample Frame). $+=$ number of times reference was made to the variable/unit of analysis. 
$\%=$ percentage of the total units of analysis as applicable to this variable. N ote: tables in this article were created by the author, from data generated from the aforementioned newspapers.

Interpretation of Data on Research Question (i) - Opposing the Grant of Asylum

Four of the positions opposed the asylum project as discussed below.

Table II: Analysis of Variable I

\begin{tabular}{lcc}
\hline Newspaper & No. of Referential Issues & $\%$ \\
\hline The Guardian & 12 & 8.39 \\
Vanguard & 18 & 12.58 \\
Total & 30 & 21 \\
\hline
\end{tabular}

Variable I concerns objections to the asylum project due to President Charles Taylor's antecedents, including being unfriendly to Nigeria and Nigerians. There were 30 referential issues on this variable constituting 21 percent of the entire units of analysis. Specifically, these issues include Taylor's dubious antecedents such as his flight to the US on account of embezzlement of $\$ 800,000$ Liberian while minister of procurement under President Samuel Doe; escaping jail in Massachusetts in 1985 while awaiting extradition to Liberia; his alignment with some African leaders notably those of Côte d'Ivoire, Burkina Faso, and Libya to launch attacks on his motherland, resulting in a seven-year war during which former President Samuel Doe was murdered. He is credited with aiding rebels in neighbouring Sierra Leone. Taylor therefore, 'is trouble personified and did not merit such [asylum] gesture'. The crisis he brought to Liberia is 'the worst example of man's inhumanity to man' so that the asylum offer is 'the most absurd gesture' (Obinor 2003: 15).

Taylor never considered Nigeria as a neutral arbiter in his contest for the leadership of Liberia. He was suspicious of the cordial relations of Nigeria's Ibrahim Babangida and Samuel Doe, alleging that the former gave military assistance to the latter's Armed Forces of Liberia (AFL). This reinforced the widely held view that the two leaders were close friends - a state of affairs attested to by the establishment of the Babangida School of International Relations at the University of Liberia and the buying over of Liberia's African Development Bank loan of $\$ 4 \mathrm{~m}$ during Doe's time by Babangida's Nigeria. Thus, Taylor's perception that Nigeria's intervention was to feather the nest of former President 
Samuel Doe to his (Taylor's) disadvantage resulted in his hatred for Nigeria and its citizens. His rebel forces thereafter gruesomely attacked Nigerians either visiting Liberia as peace keepers, monitors or journalists or even those previously resident there.

The most notorious of these attacks was the killing of two Nigerian journalists; Krees Imodibie of The Guardian and Tayo Awotusin of The Champion. These incidents are still fresh in the minds of Nigerians, and Nigeria's former Minister of Foreign Affairs, Chief Tom Ikimi (Adesina 2003: 2), , 'cautioned the Nigerian government not to disregard the feelings and sensitivities of the friends and relations of the men and women who lost their lives at he instance of Taylor and his men'. 'Charles Taylor', he concluded, 'is not a friend of Nigeria' (Adesina 2003: 2). In the same vein, Nigeria's former Military Vice-President Agustus Aikhomu insisted that given Taylor's offensive against Nigeria, the asylum offer was not just a terrible mistake on the part of President Obasanjo but a slap in the face of Nigerians and concluded that Taylor was not a friend of Nigeria (Okhomina 2003: 6).

Table III: Analysis of Variable II

\begin{tabular}{lcc}
\hline Newspaper & No. of Referential Issues & $\%$ \\
\hline The Guardian & 3 & 2 \\
Vanguard & 13 & 9 \\
Total & $\mathbf{1 6}$ & $\mathbf{I 1}$ \\
\hline
\end{tabular}

Sixteen referential issues, or eleven percent of the entire units of analysis, were generated around Variable II that gathers together objections to the asylum project because it would further drain Nigeria's already lean resources. Worse still is that similar gestures by Nigeria in the past were not appreciated. Nigeria's intervention in the Liberian crisis from 1991-2003 led it to spend $\$ 12$ billion and lose 1000 soldiers. By 1999, it had already spent $\$ 8$ billion and lost 500 soldiers (Olawale 2003: 21). On the average Nigeria was spending \$1 million daily for the up-keep of the troops and other logistics in Liberia. Testifying before a commission of enquiry on communal clashes in the Middle-Belt, former ECOMOG boss and former Chief of Staff Nigerian Army, Lt. General Victor Malu (Rtd.) noted how he brought home from Liberia an unprecedented number of corpses of Nigerian soldiers killed while on the peace mission in Liberia and he had directed that they 'be buried secretly in the night to avoid national uproar and panic' (Olawale 2003: 21). On its own, the 
Nigerian Army claimed to have expended $\mathrm{N} 135$ million on medical bills for about 150 ECOMOG soldiers with bullet and other war related injuries from the operations in Liberia. It is speculated that some 400 Nigerian ECOMOG soldiers were infected with HIV/AIDS (Olawale 2003: 21).

The sore point of the forgoing is that internally, there are serious issues begging for government attention, hence the gesture in the view of one time Federal Minister Paul Unongo smacks of charity beginning abroad instead of the other way round (Anyagafu 2003: 15). More vexatious is that these gestures were not appreciated, neither have they, in the words Sagay Isaac (2003: 11 ) 'received any gestures of gratitude commensurate with the exertions on behalf of brotherly African states' including Liberia, who has exhibited ingratitude and hostility to Nigeria. Even Charles Taylor whose ascendancy Nigeria had ensured via ECOMOG had in return hounded Nigeria and Nigerians at every opportunity.

This development is not surprising, as Nigeria has often been paid back with ingratitude by African countries to which it had been a benefactor. Nigerians are today hounded all over South Africa -- the same Nigerians from whose salaries deductions were made towards the South African Relief Fund in addition to other Nigeria's efforts at dismantling apartheid in South Africa (Animasaun 2003: 35-38). The same is true of Cameroon; a recipient of Nigeria's assistance, especially when the former experienced volcanic eruptions. Yet Cameroon has used its gendarmerie to harass Nigerian communities along its borders. What of Equatorial Guinea that allowed South Africa use it as a military base against Nigeria despite the fact that Nigeria regards Equatorial Guinea as a friend and had rallied to its assistance in moments of need (Ojieh 1994:6)? When Nigeria gave Yormie Johnson asylum in 1992, the US had undertaken to offset the bill but a former Nigerian Foreign Affairs Minister Ignatius Olisemeka observes that this was never done (Okhomina 2003: 1).

Table III: Analysis of Variable III

\begin{tabular}{lcc}
\hline Newspaper & No. of Referential Issues & $\%$ \\
\hline The Guardian & 15 & 10.5 \\
Vanguard & 19 & 13.3 \\
Total & 34 & 24 \\
\hline
\end{tabular}


Variable III has the highest number of referential issues objecting to the asylum project. It generated 34 references and constitutes 24 percent of the total units of analysis. It refers to objections to the asylum project on the grounds that: (i) the indicted President Charles Taylor was better handed over for trials by the UN Crimes Court; (ii) non-compliance to (i) could incur reprisals for Nigeria from the international community, and (iii) the concomitant effect of these threats to Nigeria's security.

Pursuant to a UN Security Council resolution 1315 of August 14, 2000 , to prosecute those allegedly responsible for atrocities in the Sierra Leone civil war, the UN's International Court for War Crimes on June 4, 2003 issued a warrant of arrest on Charles Taylor for arming rebels during Sierra Leone's long civil war (1991-2002). Specifically, Taylor was accused of 'bearing the greatest responsibility for violations of international humanitarian laws within the territory Sierra Leone since November 30 , 1996' (Okoror 2003: 1).

The indictment was approved on March 7, 2003 but was served on June 4, 2003 to coincide with Taylor's trip for the peace talks in Ghana so that the Ghanaian authorities could facilitate his arrest. Ghana did not. Nigeria was then urged not to follow Ghana's example of ignoring international covenants. In the view of Bukhari Bello, Executive Secretary of Nigeria's National Human Rights Commission, Nigeria was one of the earliest signatories of the International Crimes Court treaty and the 1998 Statute of Rome, and it is morally wrong for Nigeria to prevent Taylor's trial by the same court (Akhaine 2003: 8).

The asylum gesture, it is feared, could make Nigeria at loggerheads with the UN (Uzuakpundu 2003:44) since Amnesty International had faulted the asylum project, accusing President Obasanjo of flouting international law even as a party to the Geneva Convention (Igbintade 2003: 1). International reprisals could have included turning down Nigeria's request for a seat at the UN's Security Council. The end result of such sanctions would be total insecurity for the Nigerian state.

Table V: Analysis of Variable IV

\begin{tabular}{lcl}
\hline Newspaper & No. of Referential Issues & $\%$ \\
\hline The Guardian & 3 & 2 \\
Vanguard & 8 & 6 \\
Total & $\boldsymbol{I I}$ & $\boldsymbol{8}$ \\
\hline
\end{tabular}


Variable IV is the last of those that refer to objections to the asylum offer. In it, eleven referential issues or eight percent of the total units of analysis oppose the asylum offer on the ground that it amounts to undermining public opinion, since angry sentiments have been expressed about it since it was first announced.

Worse still was the unilateral nature of the policy since neither the National Assembly nor the Federal Executive Council was consulted. Hence, granting Taylor asylum in a manner 'lacking in proper consultation' (Okhomina 2003: 1) smacks of 'military dictatorship and insults the sensibilities of democratic norms ...' (Animasaun 2003: 37). So, Dr Usman Bugaje, Chairman, House of Representatives Committee on Foreign Affairs, has asked Nigerians to hold President Obasanjo responsible for any action of former President Charles Taylor while in exile in Nigeria (Ajanaku 2003: 3). The asylum gesture is also perceived as capable of giving credence to dissidents and bad leaders who are guaranteed a safe haven in Nigeria and thus, create more despots (Taire 2003: 11).

A combination of the arguments in variables (i) - (iv) above, answer research question (i). They tell us why Nigerians were opposed to the asylum project. They were opposed to the asylum project on the grounds of Taylor's atrocities. It was also argued that the asylum project would cause a further drain on Nigeria's economy considering the cost of providing accommodation, catering and logistics for Taylor and his large retinue, which at the first count stood at 500 with him in Calabar when he arrived August 1 1, 2003. When by August 21, no fewer than 200 more were said to have flown in; they were diverted to Uyo (Onah 2003: 3 ) apparently due to a shortage of accommodation in Calabar. Since then, the number of additional official and unofficial migrants could only be imagined.

Given Taylor's tastes and cravings, the cost of the asylum project was an 'injudicious use of public money' (Adesina 2003: 22). Making no attempt to disguise his extravagance, Taylor had hardly arrived Calabar than he began to import state-of-the art cars, furniture, cooking utensils, beddings and toiletries. This further incensed those Nigerians living in the area where he is quartered, and who did not hide their displeasure at his life style - requiring that security had to be beefed up in Calabar (Akinola 2003: 11).

Other arguments from this group of variables insist that Taylor is a UN-indicted war criminal, and Nigeria's offer of asylum amounted to 
flouting international law, which could earn Nigeria international disrepute and portend grave consequences for Nigeria's security. So, rather than the asylum offer, Nigeria should facilitate Taylor's arrest and subsequent trial at the UN Crimes Court sitting in Sierra Leone. Finally, in this line of arguments, were referential issues, which opposed the asylum offer on account of its unilateral nature and could create the impression that Nigeria was abetting impunity by protecting dictators.

But even though the asylum project may seem generally faulty in the face of Taylor's well documented misdeeds, Justice Anthony Aniagolu; a foremost Nigerian jurist points out that when Taylor committed most of those atrocities, including the killing of Nigerians, he was still a rebel leader fighting to take control of Liberia (Mamah 2003: 8). The fear of possible reprisal from the international community is mellowed by the fact that the asylum project had the tacit support of the major powers. It was a French initiative, supported by the United States, Britain and the United Nations, and Nigeria insisted that afterwards, it must not be harassed and 'intimidated' to surrender Taylor for trial (Fatunde 2003: 6).

Taylor may be a war criminal and could be held responsible for the prolonged crisis in the Mano River area, but the fact is that the International Crimes Court's warrant of his arrest was ill-timed; coming when 'it looked like there was peaceful resolution of the Liberian crisis in sight' says Professor Bolaji Akinyemi (Benson 2003: 17). He insists that it aimed at criminalising and disgracing African leaders and using Africans as scapegoats as the conduct of ICC seemed politically motivated. Otherwise, how do you explain the preference of the court beginning its hearing with the killings in the Congo which were preceded by 'so many killings we read in so many parts of the world'? Akinyemi queries.

In all, variables (i) - (iv) with a total of 91 referential issues out of 143 or 64 percent of the entire units of analysis opposed the asylum project and give sufficient grounds for us to reach the conclusion that public opinion was against the project. But why did government go ahead with the project? Perhaps an analysis of research question (ii) may provide us with a clue. 


\section{Interpretation of Data on Research Question (ii) — Supporting the Asylum}

Three of the seven variables for this work concern public support for the asylum project.

Table VI: Analysis of Variable V

\begin{tabular}{lcl}
\hline Newspaper & No. of Referential Issues & $\%$ \\
\hline The Guardian & 7 & 4.9 \\
Vanguard & 5 & 3.5 \\
Total & $\mathbf{1 2}$ & $\mathbf{8}$ \\
\hline
\end{tabular}

Variable $\mathrm{V}$ refers to arguments in support of the asylum project such as the idea that it is in consonance with Nigeria's 'big brother' role in the ECOWAS in particular and Africa as a whole. Nigeria has been responsible more than any other country for the maintenance of regional peace in Africa. Given its status in the West African sub-region, it becomes incumbent upon Nigeria to act the big brother.

Nigeria has been deeply involved in the peace efforts in Africa, West Africa and particularly in Liberia, whose two ex-war lords Prince Yormie Johnson and Roosevelt Johnson have been in exile in Ikoyi and Jos since 1992 and 1998 respectively. This is in addition to Nigeria having hosted such unpopular leaders as Mohammed Siad Barre of Somalia and Felix Malloum of Niger in the 1990s. 'Hosting Charles Taylor therefore, is only in keeping with a tradition of sheltering rejected [or put mildly, troubled] African leaders' (Omonijo 2003: 17), and a gesture for which President Bush and 'the world is grateful to Nigeria for spearheading' because removing Taylor from office in his words had been a 'tough issue' (Onurah 2003: 1 \& 2). Nigeria's role was required in providing a safe landing for US peace keepers in Liberia (Akande 2003: 1). Twelve (12) referential issues or eight percent of the units of analysis were generated from this variable.

Table VII: Analysis of Variable VI

\begin{tabular}{lcc}
\hline Newspaper & No. of Referential Issues & $\%$ \\
\hline The Guardian & 2 & 1.39 \\
Vanguard & 3 & 2.09 \\
Total & 5 & 3.5 \\
\hline
\end{tabular}


Variable VI with five referential issues or 3.5 percent of the whole units of analysis endorsed the asylum project on the grounds that it was in Nigeria's national interest, as it boosted its status as a regional and continental power. This variable is of great significance since national interest is often the core determinant of nations' foreign policies. But it is lacking in proper representation here despite Fatunde's (2003: 6) argument that since Nigerians constitute the largest number of aliens in most West African States, if Liberia goes up in further flames and destabilises, several thousands of Nigerians living in those countries as successful big time traders, spare parts traders and artisans would lose their multi-billion naira investments, return home as refugees and increase the unbearable rate of unemployment.

Thus the asylum gesture was seen as pursuant to 'Nigeria's national interest which includes the protection of her citizens'. The asylum project has shored up Nigeria's image and 'Everybody is thanking us' remarked Presidential aide Femi Fami-Kayode (Akinola 2003: 1).

Table VIII: Analysis of Variable VII

\begin{tabular}{lcc}
\hline Newspaper & No. of Referential Issues & $\%$ \\
\hline The Guardian & 16 & 11.2 \\
Vanguard & 19 & 13.3 \\
Total & 35 & 24.5 \\
\hline
\end{tabular}

With 35 referential issues or 24.5 percent of the units of analysis, Variable VII concerns support for Taylor's asylum on the grounds that the crisis in Liberia was in large part due to the oresence of Taylor, the major agent of destabilisation in the West African sub-region. The stepping down of Taylor was the surest way to peace (Sando 2003: 10) in Liberia and would 'allow West Africa as a whole to concentrate on economic development, rather than solving conflicts' (Oloja 2003: 4). Ruud Lubbers, head of the UN refugee agency, while on a tour of West Africa identified Taylor as 'the source and very embodiment of the region's problem’ (Adesina 2003: 1-2).

The stepping down of Taylor was inclusive of quitting Liberia as 'Bush tells Taylor - Quit Liberia now' (Akande 2003: 1). In the view of Ellen Johnson Sirleaf of the Unity Party of Liberia, the ceasefire signed between Taylor and the rebels in Accra on June 17, 2003 could only be of effect 'on the departure of the Liberian President' (Adesina 2003: 10). President 
Obasanjo also insisted that 'unless Charles Taylor leaves Liberia, there will be no peace' (Obinor 2003: 1-2).

To have tried to eject Taylor by force could have plunged the subregion into a war of attrition that would follow a permanent guerrilla war waged by Taylor's supporters. Hence the need for an orderly exit for Taylor in the form of asylum, and this responsibility Nigeria was to assume.

Research question (ii), which this paper sought to address was answered in the analyses contained in the arguments or variables (v) (vii). Basically, they argue in support of the asylum offer; firstly, that the asylum offer was in keeping with Nigeria's role as a major player in the sub-region's affairs making it incumbent upon it to act the big brother; including heading the peace mission into Liberia, ECOMIL, having previously headed ECOMOG in the 1990s. The argument that the asylum project was in Nigeria's national interest, however, was not frequently advanced in the sources consulted for this paper. The contention that the exit of Taylor from Liberia could bring in peace not only to Liberia but to the entire sub-region of West Africa was apparent given that it was frequently advanced.

But a distinction must be established between Taylor leaving Liberia and where he should go eventually. Nigerians were not only averse to his coming to Nigeria, but there is the possibility of Taylor still being a problem in Liberia even from Nigeria. The late Foday Sankoh had, via satellite phone calls from Abuja, directed his RUF to join forces with coup maker Johnny Paul Koroma to wreak havoc on Sierra Leone (Jason 2003: 16). Again, when in the face of the perceptions in some quarters that former President Samuel Doe was the problem with Liberia, when he died, how much peace did Liberia get?

On the whole, variables (v) - (vii) tell us the justifications for the grant of asylum. But we are still at a loss as to why this set of variables, which constituted 54 referential issues out of 143 or just 36 percent of the entire units of analysis should prevail over the arguments opposing the asylum (with higher responses) as shown above. Maybe the answers to research question (iii) could resolve this riddle.

\section{Public Opinion and Foreign Policy — Critique}

On research question (iii), the overriding of public opinion by other foreign policy determinants became known on August 1 1, 2003 when Taylor, his wife Jewel, two daughters and aides (Nwosu 2003: 1) arrived Abuja to be personally received by President Obasanjo. Obasanjo was 
earlier cautioned not to ignore public opinion on the matter of Taylor's asylum since angry sentiments had been expressed over the project. There is also the need for the leader to carry the led along especially in very crucial circumstances as the asylum project (Animasaun 2003: 37).

In liberal democracies as well as emerging ones as exemplified by Nigeria, public opinion has exerted considerable influence on foreign policy. In nineteenth century Britain, the public was proved correct when it disagreed with government policy on the American Civil War, the Russo-Turkish War, and the Boer War ((Jacobsen 1996: 105). The campaign against the Vietnam War 'actually imposed constraints and unwelcome goals on resistant policymakers and forced a reshaping of policy networks because threats like promises need to be ratified'. Thus, 'the totality of the opposition activities put pressure on officials' (Jacobsen 1996: 104) to end the war. Even now, however, President Bush remains obdurate despite the fact that the mass of Americans have become weary of America's military project in Iraq. And so, if President Obasanjo had sought the opinion of Nigerians on the asylum issue he would have received an outright 'no'.

It can be argued that 'a time comes when a professional opinion holder is called upon by duty to swim above the tide of popular view and look at the greater stakes involved in an issue' (Nnana 2003: 37). According to Dougherty (1990: 102), the primary responsibility of statesmen is the survival of the nation-state, and thus 'governmental behaviour at the international level cannot be subjected to the same moral standards that are applied to human behaviour'. 'Moreover, it is by no means certain that governments in their foreign policies express the aspirations of their peoples'. Public opinion cannot play the same role in both national and international policies because the latter is 'a matter of relations between governments and not people'. 'The conduct of an effective diplomacy is said to be difficult if not impossible, if it must be subject, both in its conception and execution, to continuous scrutiny of public opinion' (Dougherty 1990: 111). This view sees public opinion as a detrimental foreign policy determinant. It is only resorted to when not in contest with other variables particularly national interest. After other determinants may have prevailed, public opinion is used to give the people a sense of belonging. Experts' judgment of what constitutes priorities overrides the public view. Public opinion is premised on numbers while experts base their own on dynamics. Hence, even though variable (vi) (which endorsed the asylum on the grounds that it was in 
Nigeria's national interest and capable of boosting its status as a continental power) generated the least number of referential issues, the $\mathrm{Ni}$ gerian government went ahead with the project. This is because expert judgment based on dynamics has taken precedence over public opinion - supposedly a game of numbers.

When in 1960, Nigeria abrogated the Anglo/Nigeria military pact due to public outcry, Nigeria was not in immediate need of any military assistance. The truth is that it would have quickly embraced such help during the civil war if offered. Former Nigerian Head of State, General Yakubu Gowon, confessed 'I wanted to finish the war quickly ... We were short of arms and ammunition and we could not get any from Britain or anywhere.. (Gowon 2005: 35). When Nigeria led other countries to boycott international sports meetings in the 1970s and 1980s on account of public outcry against the apartheid regime's participation in the games, they gave further impetus to Nigeria's status as an emerging regional power and hence, its actions were in the national interest.

When President Babangida led Nigeria to reject the IMF loan in deference to public opinion, it was only a predetermined course of action to prepare the ground for the same IMF/World Bank, Structural Adjustment Programmes, which he had already determined to accept. This is because, according to Simmons (1993: $4 \& 281$ ), when leaders find themselves with domestic problems, they attempt 'to maintain some semblance of control' and accept or reject international 'imperatives' depending on the extent to which they meet the leaders' needs.

On the Taylor asylum issue, President Obasanjo sacrificed public opinion on the altar of national interest. This is because "no statesman, no publicist, no scholar would seriously argue that foreign policy ought to be conducted in opposition to, or disregard of, the national interest' (Dougherty 1990: 124). Nigeria's national interest here was directly involved as the implications in the event of a total conflagration in the West African sub-region were obvious. It had thus shouldered the burden of the refugees and Nigerian returnees, the high cost of restoring peace (which Nigeria had single-handedly borne before), etc. These were all higher stake issues than admitting Taylor and his retinue into Nigeria. And the last resort would be to hand Taylor over for trial. If the stake holders in the asylum project, that is, France, Britain, the US, UN, A.U, and the ECOWAS leaders (who tacitly or otherwise) endorsed the asylum offer, make a detour and decide that Taylor be turned in for trial, Nigeria will not be shamed. 
We may have argued in this article that internal factors should be considered when nations' policies respond to international stimuli, and even though variable (iv) in this article specifically argues that the asylum project undermined public opinion and was lacking in consultation, we also noted that it was a joint decision of stake holders which included the major powers, the UN, the AU, and ECOWAS with Nigeria as a leading player. Although the asylum terms may not have been made public, Elizabeth Blunt of the BBC claimed they included a comfortable accommodation for Taylor in Nigeria and a pledge that he would not be handed over for prosecution (Oyatomi 2006: 7). This seemed to have mitigated the fear of reprisal by the international community.

There is no doubt that Nigerians agreed that former President Charles Taylor should be held responsible for the crisis in Liberia and to a large extent in the ECOWAS sub-region. Hence, they appreciated that his removal from office and exile from Liberia would largely ensure peace in Liberia, the Mano River, ECOWAS and even Africa as a whole. Nigerians' aversion to the asylum for Taylor was less a rejection of the foreign policy decision of President Olusegun Obasanjo than an innate disdain for the person of Charles Taylor.

\section{Conclusion}

This article submits that public opinion does not play the first fiddle in nations' foreign policies. It is resorted to when not in conflict with other determinants - particularly the national interest as perceived by the leadership. After other determinants may have prevailed, public opinion is used to give the people a sense of belonging. When Germany's naval build-up between 1892 and 1907 aggravated tensions with Britain, the latter was restrained from aggression because 'domestic conditions minimized the chance of funding a genuine military challenge' (Jacobsen 1996: 96). When public opinion led the US to abandon Vietnam, it was because of economic considerations rather than mere mass opposition. This was because 'once the nation's resource base came under pressure, domestic calculations influenced every aspect of war' (Jacobsen 1996: 105). When Babangida claimed to have deferred to it by rejecting the IMF loan, he wanted to give the people a sense of belonging in the eventual adoption of the SAPs.

If in the West, public opinion is adumbrated as the opinion of an articulate minority since 'the vast majority of people even in highly literate societies are unknowledgeable, uninterested, and apathetic with re- 
gards to most issues of world affairs', the situation would be worse for African states including Nigeria given their low literacy levels, and other inhibitions and taboos. A closer scrutiny of the 143 referential items for this study showed that only two could be termed 'grass-roots' reactions. They even reduce to one given that they are actually the same issue but commented on by two newspapers - The Guardian 20/7/03 and Vanguard $22 / 7 / 03$, reporting on the reaction of the Ivikhua community; the home town of one of the journalist killed by rebels in Liberia. And even the grass-roots nature of this reaction could be queried as the letter of protest letter was drawn up by the Ivikhua Progressive Union, an elitist representative of the community, based in Lagos, to President Obasanjo dissenting on the asylum offer. The other 141 referential issues were elitist opinions from the Nigerian Labour Congress, Christian Association of Nigeria, Nigerian Union of Journalists, Nigerian Bar Association, Parliamentarians, government ministers, students, academics, rights' groups, etc.

If as a determinant of foreign policy, public opinion means the influence of the reactions of the public on foreign policy actions of governments, and if in Vietnam, in the German arms build-up and in the Babangida IMF loan, the public reacted among other factors to the economic effects of these government policies, it still follows that the actual influences on the changes in policies were economic and not public opinion, which is here only ancillary. Public opinion remains relevant as a foreign policy determinant if only to the extent of serving as an outlet for venting public dissent over the adverse implications of government policies.

\section{Reierences}

Adesina, D., 2003, June 20). 'AFRICAN NEWS - Liberia appeals for peacekeepers to effect cease-fire accord', The Guardian, June 30, pp. 1-2.

Adesina, D., 2003, 'Doubts Mount Over Taylor's Exit, ECOWAS Names Envoy To Liberia', The Guardian, 9 August, p.10.

Adesina, D., 2003, 'Liberia: Beyond Charles Taylor', The Guardian, 21 August, p. 22.

Aforka, N., 1988,.' Theoretical Perspective on Nigeria's Foreign Policy', in G. Olusanya, ed., Economic Development and Foreign Policy in Nigeria, Lagos: Nigerian Institute of International Affairs.

Ajanaku, I., Agba, J. \& Akaine, S., 2003, 'Reps Panel Accuses Obasanjo Over Taylor's Asylum', The Guardian, August 23, p.1.

Akande, B., 2003, 'Quit Liberia now, Bush tells Taylor', The Guardian, July 3, p.1.

Akhaine, S., 2003, 'The Political Cost of Taylor's Asylum', The Guardian, August 1, p. 8. 
Akinola, W., 2003, 'TAYLOR: Presidency explains asylum terms', VANGUARD, August 24, p.11.

Aluko, C., 1981, Essay in Nigerian Foreign Policy, London: George Allen \& Unwin Ltd.

Almond, G, 1990, 'The National-International Connection', in Almond, G., ed., A Discipline Divided: Schools and Sects in Political Science, London: Sage.

Animasaun, K., 2003, 'Asylum for Charles Taylor: The Issue', VANGUARD, June 28, pp.35-38.

Anyagafu, C., 2003, 'He can come - Unongo', VANGUARD, August 17, p.15.

Benson, D., Akinola, W. \& Bilesanmi, L., 2003, 'Warrant on Taylor: Why Obasanjo, Mbeki called UN court's bluff, by Professor Akinyemi', VANGUARD, August 17, p.17.

Conn, P., 1971. Conflict and Decision Making: An Introduction to Political Science. New York: Harper and Row.

Dougherty, J. and Pfaltzgraff, R., 1990, Contending Theories of International Relations: A Comprehensive Survey, Third Edition, New York: HarperCollins.

Eze, I. \& Kamara, B., 2003, 'Nigeria Loses 1,000 Soldiers \$12m to Liberian War', VANGUARD, July 30, pp. 1-2.

Fatunde, T., 2003, 'Why Nigeria Grants Taylor Asylum', The Guardian, July 13, p. 6.

Gowon, Y., 2005, 'Our leaders caused the civil war', VANGUARD, October 17, p.35.

Hamburg, M., 1977, Statistical Analysis for Decision Making. Second Edition, New York: Harcourt Brace Jovannovich.

Hocking, B. \& Smith, M., 1990, World Politics: An Introduction to International Relations, New York: Harvester Wheatsheaf.

Holsti, K. J., 1977, International Politics: A Framework for Analysis, New Delhi: PrenticeHall.

Holsti, O. R, 1969, Content Analysis for the Social Sciences and Humanities, Massachusetts: Addison-Wesley Publishing Company.

Igbintade, W., 2003, 'More Knocks for Obasanjo's asylum to Taylor', VANGUARD, July 11, p. 1 .

Jacobsen, J. K., 1996, 'Are All Politics Domestic? Perspectives on the Integration of Comparative Politics and International Relations Theories', Comparative Politics vol. 29, no.1, pp. 93-115.

Jason, W., 2003, 'Charles Taylor's War', VANGUARD, July 9, p.16.

Kehr, E., 1977, Economic Interest, Militarism and Foreign Policy, Berkeley: University of California Press.

Mamah, E., 2003, 'Justice Aniagolu backs asylum to Taylor', VANGUARD, July 29 , p. 8

Nnana, O., 2003, 'Charles Taylor: Another view', VANGUARD, August 25, p.37.

Nwosu, N. \& Obayuwana, O., 2003, 'Taylor arrives Abuja begins exile', The Guardian, August 11, p.1.

Obasanjo, O., 1981, My Command: An Account of the Nigerian Civil War 1967-70, Ibadan: Heinemann.

Obinor, F., 2003, 'Charles Taylor, Nigeria and asylum', The Guardian, July 10, p.15. 
Obinor, F., 2003, 'Nigeria won't obstruct Taylor's trial, says envoy', The Guardian, July 10, p. 7.

Obinor, F., 2003, 'Obasanjo decries U.S. attitude to Liberian war', The Guardian, July 30, pp. 1-2.

Ojieh, C., 1994, Nigeria's African Policy: A Study of Continuity and Change in Nigeria's South African policy 1975-1992. Unpublished M.Sc. Project in International Relations, Department of Political Science \& Public Administration, University of Benin, Benin City, p. 6.

Okhomina, O., 2003, 'Olisemeka Slams Obasanjo's asylum to Taylor', VANGUARD, July 9, p. 1 .

Okhomina, O. \& and Amaize, E., 2003, July 29 'Asylum to Taylor a terrible mistake - AIKHOMU', VANGUARD, July 29, p. 6.

Okoror, F., 2003, 'War Crime Court orders Charles Taylor's arrest', The Guardian, June 5 , p. 1.

Okpowo, B., 2003, 'Sighs as Obasanjo offers Taylor Asylum', VANGUARD, July 12 , p. 12.

Olawale, R., 2003, 'Again, Nigeria plunges into Liberia', The Guardian, July 21, p. 21.

Oloja, M., 2003, 'Liberian government, rebels sign ceasefire, Obasanjo okays pact', The Guardian, June 18, p. 4.

Omonijo, B., 2003, August 15 'THE TAYLOR ASYLUM - Repeating mistakes of history', VANGUARD, August 15, p. 17.

Omonijo, B., 2003, 'From Doe to Taylor: The Dawn of Liberian War', VANGUARD, August 17, p. 19.

Onah, G., 2003, '200 Taylor's dependants flood Calabar', VANGUARD, August 22, p. 3.

Onurah, M., 2003, July 13 'Bush Backs Obasanjo on Taylor', The Guardian, July 13, pp. 1-2.

Oyatomi, K., 2006, 'Charles Taylor off Obasanjo/Sirleaf agenda at Abuja Talks', VANGUARD, March 5, p. 7.

Peterson, P. E., 1994, 'President's Dominance of Foreign Policy', Political Science Quarterly, 109, p. 228.

Richards, D., 1967, Modern Europe 1789-1945, London: Longmans.

Sagay, I., 2003, 'Taylor and African Brotherhood', VANGUARD, July 13, p. 11.

Sando, T., 2003, 'Road Map to Peace in Liberia', The Guardian, June 14, p. 10.

Simmons, B., 1993, Who Adjusts Domestic Sources of Foreign Economic Policy during the Interwar Years?, Princeton: Princeton University Press.

Stupak, R., Gilman S. \& Hartzer, C., 1977, Understanding Political Science - The Arena of Power' New York: Alfred Knopf.

Taire, M., 2003, 'Idi Amin and Charles Taylor blood relatives', VANGUARD, August 22, p. 11.

Uzor, N., 1986, 'The Exit of Ukiwe', Thisweek: Nigeria's Authoritative Magazine, February 20, p. 17.

Uzuakpundu, N., 2003, 'Who Wants Charles Taylor?', VANGUARD, July 13, p. 44. 
